\title{
Notes From the Underground: Pop in the UK
}

1979-1982

Notes des souterrains : la pop au Royaume-Uni 1979-1982

\section{Ben Winsworth}

\section{(2) OpenEdition}

\section{Journals}

Electronic version

URL: https://journals.openedition.org/rfcb/8300

DOI: $10.4000 /$ rfcb.8300

ISSN: 2429-4373

\section{Publisher}

CRECIB - Centre de recherche et d'études en civilisation britannique

\section{Electronic reference}

Ben Winsworth, "Notes From the Underground: Pop in the UK 1979-1982", Revue Française de Civilisation Britannique [Online], XXVI-3 | 2021, Online since 14 December 2021, connection on 05 January 2022. URL: http://journals.openedition.org/rfcb/8300 ; DOI: https://doi.org/10.4000/rfcb.8300

This text was automatically generated on 5 January 2022.

\section{(c)}

Revue française de civilisation britannique est mis à disposition selon les termes de la licence Creative Commons Attribution - Pas d'Utilisation Commerciale - Pas de Modification 4.0 International. 


\title{
Notes From the Underground: Pop in the UK 1979-1982
}

Notes des souterrains : la pop au Royaume-Uni 1979-1982

\author{
Ben Winsworth
}

\section{Introduction}

The first wave of English punk as a "new" subculture and musical genre that started to attract ever growing media interest between 1976 and 1977 reflected the economic and political ills of the time, while anticipating that the worst was yet to come. However, as a present and powerful force upsetting and challenging mainstream society and the Establishment, punk seemed to have slipped out of the popular media spotlight sometime around 1979 and, perhaps with the exception of the Clash, returned to the underworld from whence it came and from where it continued to agitate, albeit in a less obviously visible manner. Crass - who never left that radical and influential underworld - testified to punk having sold out and killed itself as early as $1978 . .^{1}$ On "Punk is Dead" they castigate the damage caused by Steve Jones, the Clash, Patti Smith, the whole commercial charade, while ironically desiring their own "fifteen minutes of fame" to brutally mock those who they felt had sold out to "the system". They present a cogent and convincing argument, operating as a troubled (and troubling) conscience, yet the fifteen minutes of commercial fame that bands like the Sex Pistols and the Clash enjoyed still had an important impact. The transmission of punk through mainstream media channels helped to disseminate many of the ideas, attitudes and musical styles that Crass worked to propagate, albeit in a more radical and politically active manner. It also allowed the underground a direct and fast-track entry into the cultural, social and political consciousness of the age where songs like "White Riot" (March 1977), "Anarchy in the UK" (November 1976) and "God Save the Queen" (May 1977) could shock, upset and outrage, yet also have the potential to engage the listener in a critical exchange paradoxically heightening awareness of the system that Crass's "Punk is Dead" felt was being reinforced by signing to a major 
record company like $\mathrm{CBS}$. In the continuing broad church atmosphere of late 70s chart music that included the likes of Abba, Boney M, Village People, ELO, Cliff Richard, Paul McCartney and Wings; and where music from film soundtracks like Saturday Night Fever (1977) and Grease (1978) dominated the airwaves, ${ }^{3}$ the brief forays of punk remained, at the very least, welcome and alternative thorns in the flabby side of the popular. As such, this article will attempt to offer both survey and analysis of some the ways in which this interesting and often ambivalent relationship between the underground and the mainstream evolved in a brief, but dynamic period in the history of pop. ${ }^{4}$

\section{Jamming the System}

2 Punk, through either being rejected or evolving as a consequence of its polysemic nature, was also influential in opening up new routes for the alienated, angry or dispossessed to follow as the 1970s traded places with the 1980s and Margaret Thatcher came to dominate the political scene. Paul Weller and the Jam were caught up in the early punk explosion, but were quick to reject a movement that they felt had failed to offer the musical and cultural revolution originally promised. Even though songs on their first album In the City (May 1977) criticised Jim Callaghan, lamented the loss of the British Empire ${ }^{5}$ and they even went so far as to tell the NME that they would be voting Conservative in the next election, ${ }^{6}$ the future revealed that this was deliberate posturing designed to antagonise for its own sake rather than express any firmly held political beliefs. Having said that, the Jam already looked out of place in their adoption of a 60 s mod aesthetic and, even though they sounded punk, lyrics on early singles like "All Around the World" (July 1977) advocated a youth explosion that was not based on destruction. ${ }^{7}$ Draping Union Jacks over their amplifiers during concerts, publicity shots of the band dressed in Pete Townshend inspired red, white and blue jackets, all seemed at first glance to be reactionary gestures offering a constructive alternative to nihilism and anarchy: a putting back together of Jamie Reid's iconic ripped and safety-pinned Union Jack for the "Anarchy in the UK" publicity campaign. Even the upward mobility of mod, undergoing a late 70s revival within which the Jam found themselves being feted, seemed to anticipate something of Thatcher's own desire to encourage individuals to take responsibility for their own welfare, ${ }^{8}$ rather than the state, but the Jam were far from being the fifth columnists that they might at first have appeared to be.

3 The ironically named All Mod Cons released in November 1978 (re)confirmed the underground credibility of the band in distancing itself from the more commercial aspects of the mod revival and through self-consciously exposing - on the brief opening title track - the cynical mechanics of the industry that employed them. A cover version of the Kinks' class conscious "David Watts" and the Jam's own reworking of that theme on their self-penned "Mr Clean" in which they attack the Cambridge educated, blue suited, Times reading middle classes, also worked to establish the manner in which they would needle a mainstream society that was to become even more orthodox. Setting Sons, another autumn release, appeared a year later in November 1979 when the sun was indeed setting on a bleak decade, and at a time when many of its sons and daughters were about to experience a much darker period of recession. Although the Jam's most successful album to date and one that secured their brief future as regular "chart busters", it was a recording that reflected eerily on the new political climate of 
Thatcher's Britain and gave a bleak forecast of what was to come over the horizon. On "Wastelands" the narrator observes the rain falling and tumbling "just like our lives" on an old bomb site where post-war hope for a better future has been destroyed by the construction of "monolith monstrosities" the "Councils call homes". Now it is only possible to smile there for seconds, for smiling is an acknowledgement of life, "a brave and useless show of compassion" which has become "forbidden in this drab and colourless world". "Private Hell" underlines the isolation of the individual and the lack of any familial or social care or cohesion, while "Saturday's Kids" is an assertion of working class culture and a call for resistance against those forces that seek to ignore or suppress the lives and concerns of "real people that time has forgot". "It's the system, hate the system" chants Weller: a "system" based on the capitalist ideals expounded in "Burning Sky" where we are told that there is "no place for dreams when commerce calls" and "the wheels of finance won't begin to slow". The best thing to do is to surrender to the burning sky and the corporate, commercial future it represents: only realists and "greedy bastards" are "gonna come through" in acknowledging this higher truth. ${ }^{9}$

4 A dark commentary upon the policies championed in the 1979 Conservative General Election Manifesto, Setting Sons offers a pertinent critique of the consequences of an ideology promoting privatisation; the closure of no longer cost effective heavy industry; a reduction in health and social services; self-reliance; property ownership and less welfare from the state: all designed to redirect Government towards its primary concern of generating wealth through rewarding "hard work" unimpeded by trade union action and its bothersome defence of workers' rights. The manifesto also promised tougher action against crime through reinforcing "the rule of law" and an increase in defence spending with the clear aim of "creating a strong Britain in a free world" as part of Thatcher's overriding desire to correct the idea that "we are a once great nation that has somehow fallen behind and that it is too late now to turn things round". ${ }^{10}$

5 "The Eton Rifles", released at the end of October as a short but dynamic prequel to Setting Sons (on which it was also included) captured something of the social division and wealth inequality soon to be made worse by reactionary Conservatism and its fiscal obsessions. Even though the song was inspired by tension at a "right to work" march in Slough the previous year, ${ }^{11}$ it set the tone for the coming decade where the privately educated elite and those with money would continue to benefit and prosper while the working class and unemployed would find it harder to make ends meet in spite of flimsy promises and projects for easier access to work, financial security and home ownership. "What chance have you got against a tie and a crest?" sang Weller: a discomfiting question exposing the economic Darwinism that would characterise the 1980s. The chorus of the song, "Hello, hooray, what a nice day for the Eton Rifles" offers an ironic comment on the self confidence of the ruling classes and also - like the title of the song itself - reflects on their association with the military through the maintenance of associations like the public school army corps.

6 As the Conservative manifesto from 1979 suggests and conflict in the Falkland Islands in the spring of 1982 confirmed, one means towards restoring national pride and at least the illusion that Britain was still a relevant global power was through funding and exercising its armed forces. In "Little Boy Soldiers" Paul Weller again displays his perspicacity in commenting upon this soon to be escalating trend. The song is a 
damning criticism of blind allegiance to "Queen and country" and a veiled warning about rekindling Britain's imperial past when "we killed and shot the fucking lot....beneath the flag of democracy". God is on our side, but so too is Washington observes Weller as a reminder of where the real power lies: enough to make any Conservative on the far right of the party wince with displeasure. The album artwork of Setting Sons featuring a front cover photograph of Benjamin Clemens' The St. John's Ambulance Bearers is clearly anti-war in sentiment, while on the back cover the bulldog sitting next to a Union Jack decorated deckchair on what looks like Brighton Beach, is an ironic jibe against small island nationalism. The inner sleeve with its photograph of IWW paraphernalia and record labels decorated with portraits and scenes from the "great days" of Empire continues the political critique of the album through a visual register. ${ }^{12}$

7 Appearances on prime time TV shows like Top of the Pops to promote "The Eton Rifles" as equally successful as Setting Sons - found the Jam in the ambivalent position of being commercially successful while continuing to attack the system, particularly the new political system that Weller hated so much. "Going Underground", the next 45 release in March 1980, added to this conundrum by entering the charts at number one and staying there for three weeks. How was it possible to actually go underground while being top of the charts and attracting all of the media attention that naturally followed? Simon Reynolds has noted that punk and post-punk in the UK infiltrated the mainstream much more easily than in America, so that "you could hear The Fall and Joy Division on national radio and where groups as extreme as PiL had Top 20 hits which, via Top of the Pops, were beamed into ten million households". ${ }^{13}$ This suggests that at certain times the mainstream can be "culturally hacked" - willingly or not - by underground forces that use its easily accessible and widely distributed channels of communication to critique and agitate the conventional world from the inside. Punk had, of course, already established this trend in 1976-77, bringing the underground into the "overground", working from within to challenge everything from the values of mainstream society to the modus operandi of the music industry itself, although one could go back even further and see a similar transmutation in 1960s countercultural ideology being disseminated by the Beatles on million selling albums and singles. ${ }^{14}$

The Jam were simply following in this tradition. The picture cover of "Going Underground" showing the band staring out at the viewer from a television set is clearly and knowingly suggesting that it was through these popular channels that they would offer alternative, radical and sometimes ironic narratives to directly challenge those of the new ruling classes and the political ideology they sought to maintain. The official video with the self-reflexive presence of the TV in the studio and mimed performance of the band cut with images of nuclear mushroom clouds and photographs of former British Prime Ministers being dismissively brushed aside, adds to this idea of underground sabotage at work. ${ }^{15}$ The song itself offers a lyrical dialogue between the radical alternative of a new tomorrow and the sheep-like indifference of the present electorate blindly following a government more interested in "rockets and guns" than the NHS. In clearly stating that "I want nothing this society's got", "Going Underground' becomes a declaration of intent to maintain a combative and converse position against the status quo while seemingly being a part of it through the wealth and fame conferred. It's a position that Paul Weller maintained for the next two years on successful singles like "Funeral Pyre" (May 1981) and "Town Called Malice" (January 1982) and on the two final Jam albums, Sound Affects (November 1980) and The 
Gift (March 1982). The title of Sound Affects almost reads as a concentrated manifesto of Weller's desire to use his music as a force for revolt, the back cover even carrying a quotation from Shelley's "The Mask of Anarchy" for those unable to decode the pun in the title. Both Sound Affects and The Gift continued to offer sharply observed vignettes of recession hit Britain in the early 80s and it's possible that Weller's decision to break up the Jam at the height of their popularity in late 1982 might have had something to do with concerns about the growing politicised nature of the music being diluted through the high profile nature of the band and the media appropriation of Weller himself as a token working class hero. In many ways, and however stubborn it appeared, the ending of the Jam can be understood as a political act that gave Paul Weller the space to exercise his convictions more freely in the Style Council who, for all their success, were harder to categorise and whose militancy was more difficult to ignore. ${ }^{16}$

\section{This is the Dawning of a New Era}

9 Like the Jam, the Specials hybridised an earlier sound and style with the energy of punk, this time in a late 70s ska revival that was also popular with the new mods. However, whereas the second generation mods - both the bands (the Purple Hearts, the Chords, Squire, and Secret Affair, for example) and the new stylists themselves - were often dismissed by the music press as pale imitations of the original movement, ${ }^{17}$ the return of ska - fuelled by Jerry Dammers and his DIY vision for 2-Tone records - was regarded as a more authentic reflection of contemporary Britain and as a musical genre challenging those forces that resisted racial, social, sexual and economic equality. The 2-Tone records that flitted in and out of the charts on a regular basis between 1979-1982, gave the underprivileged a voice and attempted to wake up Middle England to the reality of life at the "(Dawning of) A New Era". ${ }^{18}$ The self-titled debut album The Specials - released just before Setting Sons in October 1979 - documents a world of urban violence and National Front supported racism ("Concrete Jungle"); teenage pregnancy and broken relationships ("Too Much Too Young", "Stupid Marriage"); neurosis and depression ("Little Bitch"); fear and paranoia in dark, unlit streets and unfriendly pubs ("Blank Expression"); unemployment and little consolation in run down clubs that contributed to the general lack of self esteem and left the punters wondering why they kept coming back ("Nite Klub"). Of course, there was consolation in the recycling of ska and the return and reshaping of its stylistic associations. In revisiting both the musical and subcultural underground of the mid-to-late $60 \mathrm{~s}$ and fusing it with the recent lessons learned from punk, the Specials spearheaded the new social realism of 2-Tone and were able to garner both alternative and mainstream kudos.

Their second album, More Specials - released in October 1980 - ultimately led to a rift in the band as a result of Dammers' desire to broaden their musical spectrum, but from a thematic point of view it dealt with familiar territory. The stark narrative on tracks like "Do Nothing" made it clear that there was not much in the way of any real future for many young people in a Britain where life had little if any meaning or reason. The lyric, "policeman comes and smacks me in the teeth" is particularly ominous. The only hope seems to lie in the narrator's use of clothes as his "only culture" as if he is trying to dress his way out of boredom and hopelessness. However, it is "fashion" rather than style that defines this "culture": something imposed rather than chosen, which at least points to the manner in which the Specials were attempting to re(dress) that through 
the creation of a 2-Tone culture encouraging young people to be themselves and resist mainstream manipulation, as difficult as that appeared to be. "Rat Race" (May 1980) not included on the UK version of the album, but a hit single in the summer - offered further sharp observation of the social divisions getting wider in British society and suggested that there has to be more to life than studying hard, working even harder and making lots of money. Middle class students talking about "Daddy's Jaguar" in the college bar while wearing political tee shirts and discussing the world situation "just for a laugh" were not going to help anyone but themselves. The "sacred college scarf" meant more and so too the opportunities that went with a privileged University education. It's not explicitly stated, but Oxbridge seems targeted here, the world in which the vast majority of Government and the ruling classes studied and from where many students would go on to get high paid jobs working for and within the financial rat race, supporting and benefiting from Thatcherism. "You're no friend of mine", sings Terry Hall voicing the anger and the discontent of the the working classes unable to access educational or career benefits with the same ease as their social superiors, in spite of Conservative pledges to the contrary. While addressed to the students in the song, "the promises you make tomorrow will carry no guarantee", could be equally well applied to Margaret Thatcher and her policy makers.

11 As many historians, cultural critics, and people who experienced the rise of 2-Tone first hand or who were part of the scene have noted, the Specials did much to counter the racial tension that characterised the early 1980s. As well as providing a musical and lyrical score that reflected a fractured country where institutional racism lay deep and where heavy handed policing, unemployment, poor housing conditions and political indifference hit black communities hardest, the Specials offered a blast of the creative potential that a multi-cultural society could realise and they kept the ideological sprit of movements like Rock against Racism alive through their direct lyrical register on tracks like "Doesn't Make It Alright". Of course, the inner city riots in Brixton, Toxteth, Handsworth and other distressed areas throughout 1981 were symptomatic of the distrust, anger and frustration felt on the ground and showed that there was still a long way to go before any kind of meaningful reconciliation could be achieved, but through its widespread dissemination and popularity, 2-Tone was an an important catalyst working to effect social and political change. Pauline Black, lead singer with the Selecter referred to 2-Tone as being a subculture in itself, an "umbrella subculture" containing many influences from rude boy, mod, skinhead and punk all working together. ${ }^{19}$ Its almost instant visible presence bypassed the traditional evolution of elitist style to mainstream fashion, but through borrowing, transforming and subverting the original subcultures it utilised, it can still be counted as an underground force, particularly in its frontline resistance to conservative/Conservative society.

Paradoxically, the Selecter were going through a stylistic crisis of their own when they released their second album Celebrate the Bullet in February $1981,{ }^{20}$ but it was more explicit in its socio-political commentary than Too Much Pressure from the previous February. "Bristol and Miami" reflects on recent riots at home and abroad - almost as a prologue to those later in the year - while "Selling Out your Future" deals with the lies propagated by politicians on TV. At a distance everything might look safe and secure in "the West", but zooming in more closely one finds poverty, resignation and fear on both the domestic and international front with the threat of nuclear destruction. Concern with atomic war was also dealt with on More Specials' "Man at C\&A" and the various versions of the Beat's "Stand Down Margaret" where "sorrow" is the 
dominant mood and any hope of a "bright future" is cancelled out by "white law" that dismisses, in particular, the black precariat and seems unmoved by the prospect of a third world war: "Would you ever give a damn? I doubt it". ${ }^{22}$

13 The Specials "Ghost Town" - released on an EP in June 1981 - has quite rightly become the song most closely associated with the domestic chaos of the early I980s. The discordant, almost funereal music and the lyrical sketch of a town - and for town read Country - that was closing down on all fronts due to economic hardship and where violence and anger were visible both on the dance-floor and outside on the streets - as the riots most clearly showed - captured perfectly the zeitgeist of the period. "Why must the youth fight amongst themselves?/Government leaving the youth on the shelf/ No jobs to be found in this country/People getting angry" all direct questions and statements urgently voiced towards and within the end of the dirge-like lamentations for the dead and dying post-industrial conurbations and inner cities. The equally unsettling video opposing the run down, decaying East End with the sleeping neoclassical buildings of the City of London formed a sharp architectural contrast between the rich and the poor, while the suitably blank expressions of the band packed tightly into the car did little to lift the spirits of the viewer. ${ }^{23}$ Even more disturbing were the passages with the band manically singing "la la la la la" as their Vauxhall Cresta swerved backwards and forwards outside and within the Rotherhithe tunnel, suggestive of the crazy journey that the country seemed bound upon and where further accidents were waiting to happen if the problems referred to in the song continued to be ignored. Even though the Specials split up shortly after this final release, their combined, collective, multi-racial presence in the car and the last shot of them standing on the banks of the Thames still manages to offer an image of hope: an underground force exercising and applying its critical acumen through a number one record and video effecting positive change in attitude and action in society at large and (perhaps) in a more profound and wide reaching manner than "The Scarman Report" and its own recommendations in the aftermath of Brixton. ${ }^{24}$

\section{New Romantics, Rebels and Reactionaries ${ }^{25}$}

On "Do the Dog", a hybridised cover version of the Rufus Thomas original included on The Specials, Jerry Dammers cites a list of all the various subcultural tribes on the eclectic contemporary scene, many of whom contributed to the creation of 2-Tone itself. Punks, Teds, natty dreads, mods, rockers, hippies and skinheads all get a mention, so too the National Front, presumably for their worrying interaction with particular youth cultures like skinhead and for a being a general source of violence and hatred in the political landscape more generally. One subculture that is not mentioned in the song, because it was only just emerging at the time the Specials' first album was being recorded, but one that made its presence felt in the early 80s during the 2-Tone years, were the soon to be called New Romantics. Although the only "new" subculture to appear at the dawn of Conservative rule it was - like many of the revivals and 2-Tone itself - contrived from a variety of stylistic and musical influences, although it appeared to have a different ideological agenda. Whereas 2-Tone grew out of the social realism of punk, New Romanticism seemed to be offering either an escape from the barren wasteland of a country in terminal decline or an endorsement of Thatcher's political response through its fetishising of wealth and glamour and in pushing the mod-ideal of 
sharp dressing and self improvement to another, almost grotesque extreme. From its modest origins in Soho at the end of the 70s in Billy's Nightclub, its transfer to Covent Garden's Blitz and eventual infiltration into the mainstream, Steve Strange, Rusty Egan and their entourage engineered an alternative revolution that took inspiration from the gender fluidity and outrage of glam, pimped up with the flamboyance of Beau Brummell and/or a more modernist, futuristic look. Robin Hood, Gerry Anderson's Thunderbirds, the Byronic hero, 1930's film stars, elements of punk and early gothic, a fascination with the French Pierrot, and the slightly later swashbuckling pirate designs of Vivienne Westwood, all coalesced in an evolving scene that celebrated difference and individuality through the diversity of its style.

Musically, as well as stylistically, the New Romantics - earlier referred to by the cognoscenti as "the cult with no name", ${ }^{26}$ "the Movement" ${ }^{27}$ or a little later, as media curiosity was aroused, Blitz Kids - rediscovered Bowie and not only Ziggy Stardust (1972), Aladdin Sane (1973) and Diamond Dogs (1974). A more profound connection was made with the so-called Berlin Trilogy ${ }^{28}$ - in particular Low and Heroes (January and October 1977 respectively) - and the music that inspired Bowie towards a more electronic, experimental aesthetic. The influence of Kraftwerk and Neu! and the dissemination of these new sounds at a time when, from a sonic perspective, punk was retreating back to American garage, revealed Bowie to be (once more) an important underground vector in anticipating and contributing to the more European turned aspects of the post-punk future..$^{29}$ German electronic music and early experimental sounds by the Human League were an integral part of Rusty Egan's "Bowie Night" playlists in what was originally much more of a subterranean dance scene than a live music culture. The only bands that can really be understood to have grown directly out of the early Blitz Kid context include the Steve Strange, Rusty Egan and Midge Ure collective, Visage and Spandau Ballet, although Spandau Ballet were quick to return to their original soul influences and shake off the Blitz Kid tag once they became a chart staple. Midge Ure's later involvement with Ultravox, George O'Dowd's Culture Club and artists as diverse as Sigue Sigue Sputnik, Sade, Marilyn, and Bananarama can all trace their origins back to the Blitz and beyond, but Visage's "Fade to Grey" (December 1980) and Spandau Ballet's "To Cut a Long Story Short" (November 1980) were more significant notes from the new underground. Lyrically, both songs are obscure and apolitical, but with slick, theatrical promotional videos they reflected the hybridised look and new electro-pop dance sound while facilitating the transition of New Romanticism into the mainstream. ${ }^{30}$ Bowie's "Ashes to Ashes" (August 1980) with its groundbreaking video and cameo performance from Steve Strange and other acolytes predated everything, ${ }^{31}$ as Bowie acknowledged his own influence upon New Romanticism through re-plundering the sound and vision that inspired it. His next single, "Fashion" (November 1980), together with the LP Scary Monsters (and Super Creeps) released in September, drew a line under his own involvement with the new "teenage wildlife", ${ }^{32}$ puncturing its pretensions and ironically flaunting the Pierrot costume on the album artwork. The album was still consumed avidly by Bowie's new devotees, but the man himself had already moved on just as the New Romantic look became part of the commercial landscape for at least the next two years.

The instigators and innovators of "the cult with no name" may have abandoned it in search of more unhackneyed domains, but Ultravox, Duran Duran, Depeche Mode, OMD, Human League, Soft Cell and others furthered the New Romantic invasion of the 
popular through cultivating the look and its electro-synth soundtrack, rapidly disseminated through the growing importance of the music video. As massive a seachange as the influence of MTV was in terms of the visual promotion of an artist taking further priority over the musical, even Adam Ant still managed to remain a force for outrage and decadence through his brief but phenomenal success and universal exposure. "Prince Charming" (1981) may well have been an extravagant and over the top record and video, ${ }^{33}$ but the chant "ridicule is nothing to be scared of" could have been penned by Bowie in the early 70s and carried with it a similar subversive energy and potential: as did the make-up of vocalists like Phil Oakey and Marc Almond. The luxuriousness and close attention to detail of New Romanticism did perhaps reflect something of the egotistical self-reliance and guilt-free celebration of wealth and success that characterised Thatcherite populism, but it still took inspiration from the DIY philosophy of punk and never totally complied with the new political landscape in which it evolved. This was an alternative form of hedonism. In an interview in a 1981 documentary, former punk Jordan stated that during times of economic depression "with people like Margaret Thatcher who put such a great downer on people... the inclination is for people to look rich and look healthy and look up" ${ }^{34} \mathrm{~A}$ recurrent pattern in British youth subcultural experience: resistance through self-assertion in ironic and extravagant ways that subverts and - in the case of the New Romantics perverts the expectations and aspirations of the broader community.

\section{Conclusion}

17 New Romanticism, that was quickly elevated from the underground into mainstream popularity in the early months of Thatcher's long tenure, provided a stylistic and creative opposition against a Conservative manifesto that questioned what was happening to "our country" and lamented the loss of traditional values that "we used to share". ${ }^{35}$ Through negotiating an ambivalent space between the underground and the mainstream, it promoted - like a great deal of youth culture in the period - an alternative discourse that, because of its high visibility, was open and accessible as a locus for young people to experience and experiment with. At a time in British popular cultural history when the concrete floor encasing the underground revealed itself to be still porous, it offered - to quote from Marc Almond - "a great chance to be subversive, to get other ideas and other things across to people" ${ }^{36}$ confirming that commercially successful pop and its performance still had the potential to remain a potent force for the articulation and expression of difference. It might not have altered the voting habits of a majority who made sure that the Conservatives would consolidate their power for the foreseeable future (and even beyond that), but it gave a vital sense of agency to those who either refused to comply with that majority or sought more active forms of resistance through working with the subcultural and musical material available to them. In this article I have looked at the impact of this activity within the context of its own time (1979-1982), but space remains for closer scrutiny of the ways in which it shaped and influenced culture and society more widely in the final years of the twentieth century and on into the new millennium. 


\section{BIBLIOGRAPHY}

Albertson, Kevin and Stepney, Paul, '1979 and all that: a 40-year reassessment of Margaret Thatcher's legacy on her own terms', Cambridge Journal of Economics, Volume 44, Issue 2, March 2020, Pages 319-342, https://doi.org/10.1093/cje/bez037 consulted 17 March 2020.

Bonner, Michael, 'The making of 'the Eton Rifles' by the Jam', Uncut Magazine, 25 May, 2016, https://www.uncut.co.uk/features/making-eton-rifles-jam-77021/2/ consulted 30 March 2020.

Bushell, Gary, Time for Action: The Mod Revival 1978-1981 (London: Countdown Books, 2012).

Butler, Marilyn, Romantics, Rebels and Reactionaries: English Literature and its Background 1760-1830 (Oxford, OUP, 1985).

Campbell, Kenneth L, The Beatles and the 1960s: Reception, Revolution and Social Change (London: Bloomsbury, 2022).

Clarke, S, 'All Change and back to 1964...the Jam', New Musical Express (7 May, 1977).

Collier, Jason, dir. Two Tone Britain, Channel 4 Documentary, 2004, https://www.youtube.com/ watch?v=ueMDcBp5tQU consulted February- March 2020.

Halperin, Shirley, “Stand Down Margaret': English Beat's Dave Wakeling Reflects on AntiThatcher Anthem', The Hollywood Reporter, 4 September, 2013, https:// www.hollywoodreporter.com/news/stand-down-margaret-english-beats-435073 consulted February 282020.

Jones, Dylan, Sweet Dreams: The Story of the New Romantics (London, Faber and Faber, 2020).

Lindsay, Matthew, 'Strange Fascination: the New Romantics', The New Romantics (Digital Edition) 2019, http://pocketmags.com purchased March 2020.

Mullen, John, 'UK Popular Music and Society in the 1970s', Revue Française de Civilisation Britannique, XXII: Hors Série, 2017, https://journals.openedition.org/rfcb/1695 consulted October 222021.

Pasini, Carlos, dir. Posers: The New Romantics, AB7 Productions Documentary, 1981, https:// www.youtube.com/watch?v=w8ekIDJKDRE consulted February-March 2020.

Reynolds, Simon, Rip it Up and Start Again: Post-Punk 1978-1984 (London, Faber and Faber, 2005).

Rimmer, David, New Romantics: The Look (London, Omnibus Press, 2013).

Rodgers, Jude, 'Marc Almond: 'I've had the chance to be subversive in the mainstream", The Guardian, 23 October, 2016, https://www.theguardian.com/music/2016/oct/23/marc-almondtrials-of-eyeliner-soft-cell-bowie-interview-subversive-mainstream consulted January 162020. Scarman, Lord John, The Brixton Disorders, 10-12th April (1981) (London: HMSO, 1981).

Stanley, Bob, Yeah, Yeah, Yeah: The Story of Modern Pop (London, Faber and Faber, 2014).

Stanley, Bob, Yeah, Yeah, Yeah: The Story of Modern Pop (London, Faber and Faber, 2014).

Tranmer, Jeremy, 'Political Commitment of a New Type? Red Wedge and the Labour Party in the 1980', Revue Française de Civilisation Britannique, XXII:3, 2017, https://journals.openedition.org/ rfcb/1466 consulted April 102020. 
Winsworth, Ben, 'All Mod Cons: Back to the Future with the Jam' in Lee Brooks, Mark Donnelly and Richard Mills (eds), Mad Dogs and Englishness: Popular Music and English Identities (London, Bloomsbury, 2017), pp.54-66.

Worley, Matthew, No Future: Punk, Politics and British Youth Culture 1976-1984 (Cambridge, CUP, 2017).

References and quotations from The Conservative Party Election Manifesto (1979) and Margaret Thatcher's speech at the Conservative Political Centre Summer School (July 1979) are taken from The Margaret Thatcher Foundation website: https://www.margaretthatcher.org, copyright from the estate of Lady Thatcher, reprinted with permission.

\section{NOTES}

1. Although the phrase "punk is dead" was already coined in 1977. See Matthew Worley, No Future: Punk, Politics and British Youth Culture 1976-1984 (Cambridge, CUP, 2017), p.253.

2. Included on the album, The Feeding of the 5000, recorded October 1978, although the release was delayed due to workers at the Irish pressing plant refusing to manufacture such blasphemous content.

3. For an interesting analysis of the generic variety, influence and reception of 70s pop, see John Mullen, "UK Popular Music and Society in the 1970s", Revue Française de Civilisation Britannique, XXII: Hors Série, 2017, https://journals.openedition.org/rfcb/1695

4. Like Bob Stanley I use the term "pop" in an all inclusive sense. Yeah, Yeah, Yeah: The Story of Modern Pop (London, Faber and Faber, 2014), p. xiii.

5. On the track "Time for Truth".

6. S. Clarke, “All Change and Back to 1964...the Jam", New Musical Express, 7 May, 1977.

7. "What's the point in saying destroy? I want a new life for everywhere".

8. In a speech at the Conservative Political Centre Summer School in July 1979, Mrs Thatcher advocated the need for families and neighbours to look after themselves and criticised the "collective ethos" cultivated by Socialism that "has made individuals excessively prone to rely on the State". It was to become a familiar mantra. https://www.margaretthatcher.org/document/ 104107

9. For an illuminating analysis of wealth inequality and the failure of Thatcher's economic policies during the 1980s, see Kevin Albertson and Paul Stepney, "1979 and all that: a 40 year reassessment of Margaret Thatcher's legacy on her own terms", Cambridge Journal of Economics, Volume 44, Issue 2, March 2020, pp. 319-342, https://doi.org/10.1093/cje/bez037

10. Conservative General Election Manifesto, April 1979: https://www.margaretthatcher.org/ document/110858

11. Michael Bonner, "The Making of 'the Eton Rifles' by the Jam", Uncut Magazine, 25 May 2016: https://www.uncut.co.uk/features/making-eton-rifles-jam-77021/2/

12. For further analysis of the iconography of All Mod Cons and Setting Sons see Ben Winsworth, "All Mod Cons: Back to the Future with The Jam" in Brooks, Lee, Donnelly, Mark and Mills, Richard (eds), Mad Dogs and Englishness: Popular Music and English Identities (London, Bloomsbury, 2017) pp.54-66.

13. Simon Reynolds, Rip it Up and Start Again: Post-Punk 1978-1984, (London, Faber and Faber, 2005), p.xv.

14. See, for example, Kenneth L. Campbell's recent study, The Beatles and the 1960s: Reception, Revolution and Social Change, (London, Bloomsbury, 2022).

15. https://www.youtube.com/watch?v=AE1ct5yEuVY 
16. Paul Weller and the Style Council were one of the groups heavily involved in the Red Wedge collective of artists campaigning for the Labour Party in the run up to the 1987 General Election. See Jeremy Tranmer, "Political Commitment of a New Type? Red Wedge and the Labour Party in the 1980s", Revue Française de Civilisation Britannique, XXII : 3, 2017, https:// journals.openedition.org/rfcb/1466

17. See Gary Bushell, Time for Action: The Mod Revival 1978-1981 (London, Countdown Books, 2012), pp.99-100. The Jam, even though they distanced themselves - somewhat disingenuously - from the mod revival, were spared similar criticism from the music press for maintaining a more obvious political lineage with the first wave of punk.

18. Written by Jerry Dammers and included on side two of the The Specials.

19. Two Tone Britain, Channel 4 Documentary, directed by Jason Collier, written and produced by Dave Rimmer (2004): https://www.youtube.com/watch?v=ueMDcBp5tQU

20. Personnel changes and a new artistic direction and image moved the band away from the classic 2-Tone look of 1979. Like Madness and the Beat, the Selecter were only an "official" 2Tone band for a brief period, but like their fellow travellers have remained forever associated with Jerry Dammers' label.

21. Included on the Beat's debut album I Just Can't Stop It (May 1980) as part of a medley with a version of Prince Buster's "Whine and Grine". Later released in a dub version as a double "A" side 45 with "Best Friend" the following August.

22. Dave Wakeling reflects on the song and more generally on life in Thatcher's Britain in The Hollywood Reporter, 4 September 2013, as told to Shirley Halperin: https:// www.hollywoodreporter.com/news/stand-down-margaret-english-beats-435073

23. https://www.youtube.com/watch?v=RZ2oXzrnti4

24. Lord J. Scarman, The Brixton Disorders, 10-12th April (London: HMSO, 1981).

25. With apologies to Marilyn Butler, Romantics, Rebels and Reactionaries: English Literature and its Background 1760-1830 (Oxford, OUP, 1985).

26. Matthew Lindsay observes that Steve Strange "always preferred 'the Cult With No Name' to New Romantics: it suggested a lack of fixed identity." "Strange Fascination: the New Romantics", The New Romantics (Digital Edition, 2019) p.15: http://pocketmags.com

27. David Rimmer, New Romantics: The Look (London, Omnibus Press, 2013) p.10.

28. Low (1977), Heroes (1977) and Lodger (1979). Gary Numan was also responsible for ushering in futuristic, synthesised sounds with the Tubeway Army release "Are 'Friends' Electric?" (May 1979) that spent four weeks at number one and heralded the new wave of British synth-pop in the UK Singles Chart.

29. Obviously with more than a little help from Brian Eno!

30. https://www.youtube.com/watch?v=JE2sCISQmpE; https://www.youtube.com/watch? $\mathrm{v}=\mathrm{UMPC} 8 \mathrm{QJF} 6 \mathrm{sI}$

31. https://www.youtube.com/watch?v=HyMm4rJemtI

32. The track "Teenage Wildlife" that opens side two of Scary Monsters certainly seems to be taking a swing at Steve Strange and the Blitz Kids: "A broken nosed mogul are you/One of the new wave boys/Same old thing in brand new drag/Comes sweeping into view".

33. https://www.youtube.com/watch?v=9p__WmyAE3g

34. Posers: The New Romantics, AB7 Productions Documentary, directed by Carlos Pasini, written and produced by Maggie Norden (1981): https://www.youtube.com/watch?v=w8ekIDJKDRE

35. op. cit.

36. Interview with Jude Rogers, The Guardian, 23 October 2016: https://www.theguardian.com/ music/2016/oct/23/marc-almond-trials-of-eyeliner-soft-cell-bowie-interview-subversivemainstream 


\section{ABSTRACTS}

This article will consider the ways in which some of the pop music produced in the late 1970s and early 1980s offered critical commentary upon Margaret Thatcher's Britain from within a commercial context. Bands like the Jam and the Specials provided alternative, radical and sometimes ironic narratives that directly challenged those of the new ruling classes and the political ideology they sought to maintain. Although high profile, they carried the energy of the underground into the mainstream, using popular media forms to contest the morals and ideals that conservative society worshipped. Similarly, subcultural movements like the New Romantics, quickly elevated from the underground into mainstream popularity in the early months of Thatcher's first term, celebrated plurality and difference and provided stylistic and creative resistance against the 1979 Conservative Election Manifesto that sought a solid return to a more traditional sense of values.

Cet article examinera la manière dont une partie de la musique pop produite à la fin des années 1970 et au début des années 1980 proposait des commentaires critiques sur la Grande-Bretagne de Margaret Thatcher dans un contexte commercial. Des groupes comme le Jam et les Specials ont fourni des récits alternatifs, radicaux et parfois ironiques, qui ont directement défié les discours des nouvelles classes dirigeantes et l'idéologie politique que celles-ci cherchaient à maintenir. Bien que très médiatisés, ils ont transporté l'énergie de l'underground dans le courant dominant, utilisant des formes de médias populaires pour contester les mœurs et les idéaux que la société conformiste adorait. De même, les mouvements sous-culturels comme les New Romantics, rapidement passés de la clandestinité à la popularité dominante dans les premiers mois du premier mandat de Thatcher, ont célébré la pluralité et la différence et ont fourni une résistance stylistique et créative contre le manifeste électoral conservateur de 1979 qui cherchait un solide retour à un sens traditionnel des valeurs.

\section{INDEX}

Mots-clés: pop, underground, société dominante, sous-culture, conservateur, résistance

Keywords: pop, underground, mainstream society, subculture, Conservative, resistance

\section{AUTHOR}

\section{BEN WINSWORTH}

Université d'Orléans, REMELICE EA4709

Ben Winsworth is senior lecturer in English Literature and Popular Culture at the University of Orléans where he teaches - among other things - the history and analysis of popular music and an introduction to youth subcultures in the UK. He has published a variety of articles and book chapters on twentieth-century British fiction and pop/rock in the 1960s and 1970s. 